\title{
Correlation Between Epidural Hematoma Volume In Temporal Region With Glasgow Coma Scale On Patients With Head Injury At Haji Adam Malik General Hospital Medan In The Year Of 2018
}

\author{
Ruth Jean Tri Apriliyanty ${ }^{1}$, Sabri $^{2}$, Delyuzar $^{3}$, Ridha Dharmajaya ${ }^{4}$ \\ ${ }^{1}$ Faculty of Medicine, Universitas Sumatera Utara, Medan, North Sumatera, Indonesia \\ ${ }^{2,4}$ Department of Neurosurgery, Faculty of Medicine, Universitas Sumatera Utara, Medan, North \\ Sumatera, Indonesia \\ ${ }^{3}$ Department of Anatomic Pathology, Faculty of Medicine, Universitas Sumatera Utara, Medan, North \\ Sumatera, Indonesia
}

\begin{abstract}
Epidural hematoma (EDH) is the type of intracranial haemorrhage due to head injury that occur most frequently. EDH volume usually stable and can reach the maximum volume in only a few minutes or hours after traumatized. EDH being attentive to the clinicians and researchers because of the enforcement diagnosis that is relatively easy and the rate of success in operation is quite high and EDH located in temporal region contributed to increasing the mortality due to respiratory arrest from uncal herniation because of brainstem compression. Measuring degrees severity EDH the most common and much worn in international is glasgow coma scale (GCS) because it has a high level of validity; reliability, sensitivity and specificity. This research was conducted to see correlation between EDH volume in temporal region with GCS in patients with head injury. Research conducted is analytic observation with cross-sectional approached study. The study sample is 45 epidural hematoma patients in temporal region at productive age (18-59 years) who had diagnosed and got the best act of resuscitating to know the score GCS at H. Adam Malik General Hospital in 2018 who had met the inclusion and exclusion criteria. The technique of taking data is consecutive sampling from medical record. Statistically there are negative relations between GCS to the volume of EDH patients based on the results of the CT scan ( $<<0,001$, CI $95 \%$ ) with the 0,619 relations that is indicative of the strength of the relations which is very strong.
\end{abstract}

Keyword: Head Injury, Epidural Hematoma (EDH), Glasgow Coma Scale (GCS)

\begin{abstract}
Abstrak. Epidural Hematoma (EDH) merupakan jenis perdarahan intrakranial akibat cedera kepala yang paling banyak terjadi. Volume EDH biasanya stabil, dan dapat mencapai volume maksimum hanya beberapa menit atau jam setelah trauma. EDH menjadi perhatian bagi para klinisi dan peneliti karena penegakkan diagnosis yang relatif mudah dan keberhasilan operasi yang cukup tinggi dan EDH yang berlokasi di regio temporal berkontribusi meningkatkan angka mortalitas karena dapat menyebabkan terjadinya henti napas karena herniasi unkus yang dapat menekan batang otak. Pengukur derajat keparahan epidural hematoma yang paling umum dan banyak dipakai di Internasional adalah Glasgow coma scale(GCS) karena memiliki tingkat validitas, reliabilitas, sensitivitas dan spesifisitas yang tinggi. Penelitian ini dilakukan untuk melihat hubungan volume epidural hematoma di regio temporal dengan glasgow coma scale pada pasien cedera kepala. Penelitian yang dilakukan bersifat analitik observasional dengan
\end{abstract}

*Corresponding author at: University of Sumatera Utara 
pendekatan studi cross-sectional. Sampel penelitian adalah pasien epidural hematoma di region temporal pada usia produktif (18-59 tahun) yang sudah didiagnosis dan telah mendapatkan tindakan resusitasi untuk mengetahui skor glasgow coma scale terbaik di RSUP H. Adam Malik Medan pada tahun 2018 serta telah memenuhi kriteria inklusi dan eksklusi. Teknik pengambilan data adalah secara consecutive sampling rekam medik. Secara statistik terdapat hubungan negatif bermakna antara GCS dengan volume perdarahan pasien EDH berdasarkan hasil pemeriksaan CT scan (p<0,001, CI 95\%) dengan kekuatan hubungan 0,619 yang menunjukan kekuatan hubungan yang sangat kuat.

Kata Kunci: Cedera Kepala, Epidural Hematoma (EDH), Glasgow Coma Scale (GCS)

Received [10 Feb 2020] | Revised [17 Mar 2020] | Accepted [25 Mar 2020]

\section{Introduction}

Head injury is one of global health problem that cause deaths, disabilities and also mental deficits [1]. North Sumatera province itself shows injury cases of 7,2\% [2]. Head injuries is one of the factor that cause intracranial bleeding. Based on data, $2 \%$ from whole head injury cases is epidural hematoma (EDH), and about 5-15\% patients with severe head injury is EDH [3]. Epidural hematoma (EDH) is a clump of blood between dura mater and internal tabula due to trauma. This bleeding often happens in temporal area when one of the meningea media artery branch ruptured. EDH on temporal region becomes an attention towards clinicians and researchers because it is one of the highest cases between the four types of bleeding, diagnosis that is relatively easy and the success of operation is quite high [4] and based on previous research, it is said that EDH located in temporal region contributed to increasing the mortality due to respiratory arrest from uncal herniation because of brainstem compression [5]. EDH surgery is recommended as soon as possible after diagnosis is established, because the faster the surgery is done, then the higher benefits that could be achieved [4].

Glasgow coma scale (GCS) that is done after resuscitation is the most common and used in International to measure the head degree, even in neurotrauma research. The main benefit from GCS is it is moderate and its function as standard measurement could be used to compare its result in patients [6]. Based on the background above, as well as the lack of research, especially in Medan which relates the volume of epidural hematoma with the glasgow coma scale, the author is interested to do a research about correlation between epidural hematoma volume in temporal region with glasgow coma scale on patient with head injury at Haji Adam Malik General Hospital Medan in the year of 2018.

\section{Method}

This study method is an observational analytic with cross sectional approach. In cross sectional studies the independent variable and the dependent variable were assessed simultaneously at one time. This study was conducted in Haji Adam Malik General Hospital Medan. The period of this study was July-December 2019. Sampling method is consecutive sampling in accordance 
with the criteria of inclusion and exclusion, where the samples are taken in the order of coming to meet the minimum number of samples.

Determination of sample size in research use the formula :

$$
\mathrm{n}=\frac{(\mathrm{z} \alpha+\mathrm{z} \beta)^{2}}{\left\{0.5 \ln \left(\frac{1+r}{1-r}\right)\right\}^{2}}+3
$$

Information :

$$
\begin{aligned}
& n=\text { minimal number of samples } \\
& z \alpha=1,96 \\
& z \beta=1,28 \\
& r=0,464[7,8]
\end{aligned}
$$

The minimum number of samples from this study is 45 people. Sampling using consecutive sampling techniques. Technique is done by taking samples according to the inquired criteria that has been standardized.

Data processing and analysis use 5 stages, namely data collection, data processing, data presentation, data analysis/ interpretation, and conclusions. The data obtained is entered into SPSS (Statistical Package for the Social Sciences) and distributed using frequency distribution tables and carried out discussions using existing libraries. Before using bivariable analysis, normality test is done for GCS score data with bleeding volumes based on head CT scan with Shapiro-Wilk Test for the number of samples less than 30 people or with One Sample Kolmogorov-Smirnov Test for number of samples more than 30 people and stated normal when $p>0.05$. Next do a bivariate analysis to see whether there is correlation between independent variable and the dependent variable. The statistical test used is the Pearson Correlation Test which is a parametric hypothesis test, if both variable are normally distributed or the Spearman Correlation Test is used if one or both variables are not normally distributed. 


\section{Result}

Table 1. Samples Characteristic

\begin{tabular}{cccc}
\hline Variable & Category & Frequency & Percentage \\
\hline Gender & Men & 35 & 77.8 \\
Age & Women & 10 & 22.2 \\
\multirow{3}{*}{ Head Injury Degree } & $18-40$ & 37 & 82.2 \\
& $40-59$ & 8 & 17.8 \\
EDH Volume & Mild Head Injury & 22 & 49 \\
& Moderate Head Injury & 16 & 35.5 \\
& Severe Head Injury & 7 & 15.5 \\
& $1-10$ & 9 & 20 \\
& $11-20$ & 5 & 11.1 \\
& $21-30$ & 6 & 13.3 \\
& $31-40$ & 8 & 17.8 \\
& $41-50$ & 8 & 17.8 \\
& $51-60$ & 4 & 8.9 \\
& $61-70$ & 1 & 2.2 \\
& $71-80$ & 2 & 4.4 \\
& $81-90$ & 1 & 2.2 \\
& $91-100$ & 0 & 0 \\
& $101-110$ & 0 & 0 \\
& $111-120$ & 1 & 2.2 \\
& & $\mathbf{4 5}$ & \\
& TOTAL & &
\end{tabular}

Table 1 shows the characteristic of all samples in this study. EDH victims are mostly suffered by men (77,8\%). Based on age, it often suffered by age group of young adults (18-39\%) by $82,2 \%$ with mean age of 29,02 years old. EDH victims in the beginning of treatment has mild stage which is mild head injuries (13-15) about 49\% and EDH volume varies, with mean of $35,77 \mathrm{cc}$.

Table 2. Correlation between EDH volume with GCS

\begin{tabular}{ccc}
\hline Spearman Correlation & R & p-value \\
\hline EDH Volume $><$ GCS & $-0,619$ & $<0,001$ \\
\hline
\end{tabular}

As shown in table 2, spearman correlation is used to assess the correlation between volume epidural hematoma in temporal region with glasgow coma scale in patients with head injury. The result shows that there is significant correlation between volume epidural hematoma in temporal region with glasgow coma scale in patients with head injury $(p$-value $=-0,619)$. The type of correlation in these study is negative correlation, which meant if the value of one variable (volume of EDH) increases, then the value of the other variable (GCS) will decreases. 


\section{Discussion}

Based on gender, EDH incidents in Haji Adam Malik General Hospital Medan that has been this research samples is mostly suffered by men compared to women. This is parallel with the previous research that shows that majority of EDH patient is men with the percentage of $>75 \%$ $[9,10,11]$. This also corresponds to the theory that states men is four times more often suffers from EDH incident compared to women. This is related to productive men's activities, profession and driving pattern [7].

Based on age, it can be seen that most EDH patients are young adults (18-39 years). The results of this study are supported by previous studies which showed that the highest incidence of EDH cases occurred in the young adult age group of 20-30 years [3, 12]. In accordance with the theory that states that adolescents and young adults are very susceptible to head injuries. This is because this age group often performs activities that are at risk of causing head injuries because they are in the most active period of life [7]. Cases of EDH rarely occur at the age above 60 years, this is caused by old age anatomically, the attachment of the dura mater in the skull bones is getting stronger so it is difficult to provide a gathering place for epidural haemorrhage [3].

Based on the degree of head injury, the most frequent cases of EDH are minor head injuries (GCS 13-15). This is consistent with previous research which states that the majority of EDH patients are categorized as minor head injuries with a percentage of $61-83 \%$ [11, 13, 14, 15]. This is consistent with the theory that the accumulation of blood formed in EDH is located on the outside of the dura mater so that it does not directly interfere with brain tissue and is usually caused by low energy collisions [7].

In this study it was found that the EDH volume range in Haji Adam Malik General Hospital Medan varies and most in the 1-10 cc volume category. The lowest EDH volume is $3 \mathrm{cc}$ and the highest is $114 \mathrm{cc}$. This is in parallel with the previous studies which showed vary EDH volumes with the results of research showing the lowest volume of $31.4 \mathrm{cc}$ and the highest volume of 205 cc [16]. This shows that EDH can occur with very low or very high bleeding volume depending on the mechanism, strength and direction of the injury [17].

In this research, it shows that there are significant negative relation between GCS and bleeding volume on EDH patients in Haji Adam Malik General Hospital Medan with the value $p<0.001$ ( $>0.05$ ) and a correlation strength of 0,619 that shows a strong correlation. This is parallel with the previous study that states that there is significant correlation with the increase GCS score, $73,1 \%$ has a lowering volume number of bleeding that can be seen through CT Scan. In contrast, patients who has a worsening GCS score, $77.9 \%$ had an increasing amount of intracranial bleeding volume. Therefore the authors conclude that the CT scan is only performed in patients with clinical deterioration due to an unexplained increase in intracranial pressure [18]. 
Other studies states that there is a correlation between patients GCS score with CT scan results in EDH patients [19]. Another research shows that there is a negative correlation between bleeding volume and GCS score in intracerebral haemorrhage patients who have a correlation value of 0.599 or shows a moderate correlation, whereas other research at North Phanom Hospital states that there is a significant correlation between GCS scores and bleeding volume in the incident of head injury with a $\mathrm{p}$ value $<0.001$. The correlation between GCS scores and volume of $\mathrm{EDH}$ is due to the more bleeding volume that accumulates intracranially, the more the brain structure is disturbed so that it will cause a decrease in consciousness. The results of this study indicate that GCS scores can be the initial predictors for assessing the volume of bleeding in patients before a CT scan [7].

In Indonesia, research that is conducted Hasan Sadikin General Hospital Bandung, states that there is a significant correlation between GCS and bleeding volume of epidural hematoma patients that is measured using $\mathrm{ABC} / 2$ measurements, based on the result of CT Scan ( $<<0,001$, CI 95\%) with a correlation strength of 0.68 which indicates a very strong correlation [7].

\section{Conclusion}

There is significant correlation between volume of epidural hematoma in temporal region with glasgow coma scale in patients with head injury.

\section{REFERENCES}

[1] Kumar, R. 2013, Dasar-dasar Patofisiologi penyakit. Jakarta : Binarupa aksara.

[2] Kemenkes RI. 2013, Riset Kesehatan Dasar; RISKESDAS. Jakarta: Balitbang Kemenkes RI

[3] Santoso, M., Rahayu, M. \& Balafif, F. 2015, Correlation Of Severe Head Injury Epidural Hematoma Trepanation Respond Time With Outcome. [online] Available at: http://dx.doi.org/10.21776/ub.mnj.2016.002.01.3 [Accessed 30 Apr. 2019].

[4] Perron, A. D. 2008, How to read a head CT Scan, In Injuries to Bones and Organs, New York, Mc Graw Hill., Chp 69: 356 - 358.

[5] AV Ciurea, R. 2019, A life threatening problem in infants: supratentorial epidural hematoma. [online] PubMed Central (PMC). Available at: https://www.ncbi.nlm.nih.gov/pmc/articles/PMC3018979/ [Accessed 15 Nov. 2019].

[6] Saputra, I. 2014, Hubungan Hasil Rotterdam Ct Score Dengan Glasgow Outcome Scale Pada Pasien Cedera Kepala Yang Dilakukan Operasi Kraniectomi Dekompresi. [online] Available at: http://repository.usu.ac.id/bitstream/handle/123456789/ 41472/Chapter\%20II.pdf?sequence=4\&isAllowed=y [Accessed 30 Apr. 2019].

[7] Budiman, D. A. 2017, Hubungan Gcs Dengan Volume Perdarahan Berdasarkan CtScan Kepala Pasien Epidural Hematoma Di Rumah Sakit Hasan Sadikin Periode Januari-Desember 2015.

[8] Rojanapong, N. 2013, Correlation between glasgow coma score (GCS) and blood volume from CT scan brain at nakhonphanom hospital: case study of traumatic brain injury (TBI). PKP 2013; 15(1): 80-8.

[9] Rosyidi, R., Priyanto, B., Al Fauzi, A. and Sutiono, A. 2019, Toward zero mortality in acute epidural hematoma: A review in 268 cases problems and challenges in the developing country. Interdisciplinary Neurosurgery, 17, pp.12-18.

[10] Peres, C., Caldas, J., Puglia, P., de Andrade, A., da Silva, I., Teixeira, M. and Figueiredo, E. 2018, Endovascular management of acute epidural hematomas: clinical experience with 80 cases. Journal of Neurosurgery, 128(4), pp.1044-1050. 
[11] Gutowski, P., Meier, U., Rohde, V., Lemcke, J. and von der Brelie, C. 2018, Clinical Outcome of Epidural Hematoma Treated Surgically in the Era of Modern Resuscitation and Trauma Care. World Neurosurgery, 118, pp.e166-e174.

[12] Zollman, F. S. (ed) 2016, Manual of Traumatic Brain Injury: Assessment and Management, 2nd edn, Demos Medical Publishing, New York.

[13] Hannan, M., Rafiq, A., Nazir, M., Malik, S., Farooq, M., Murtaza, G., Jabbar, H. \& Gilani, A. 2019, Correlation of Glasgow Coma Scale (GCS) with Computed Tomography $(C T)$ in Patients of Intra-Cranial Injuries. Journal of Health and Medical Sciences, 2(2).

[14] Saanin, S., Amrizal. 2018, Mortality Influenced Factors for Outcome of Epidural Hematoma Patient Which Performed Emergency Craniotomy in M Djamil Hospital Padang Periode January-December 2017. Jurnal Kesehatan Andalas, [online] 7(3), pp.26-28. Available at: http://jurnal.fk.unand.ac.id [Accessed 15 Oct. 2019].

[15] Boris K, Ashkenazi I, Rauf ZA, Alicia N, Alexander K, et al. 2013, Is Routine Brain CT Scan, Performed for Early Follow Up in Head Trauma Patients with GCS 14-15, Always Justified?. J Trauma Treat. 2:174. doi:10.4172/2167- 1222.1000174

[16] Soon, W. C., Marcus, H., \& Wilson, M. 2016, Traumatic acute extradural haematoma - Indications for surgery revisited. British Journal of Neurosurgery, 30(2), 233234. doi:10.3109/02688697.2015.1119237

[17] Al-Mochdar, S. 2005, Epidural Hematoma: Studi Retrospektif Deskriptif mengenai Beberapa Faktor yang Mempengaruhi Hasil Akhir Penderita Epidural Hematoma di RSUPN CM Periode Tahun 2001-2004.

[18] Lee, T., Aldana, P., Kirton, O. \& Green, B. 1997, Follow-up computerized tomography $(C T)$ scans in moderate and severe head injuries: Correlation with Glasgow coma scores (GCS), and complication rate. Acta Neurochirurgica, 139(11), pp.1042-1048.

[19] Ndoumbe, A., Patience Ekeme, M., Simeu, C. and Takongmo, S. 2018, Outcome of Surgically Treated Acute Traumatic Epidural Hematomas Based on the Glasgow Coma Scale. Open Journal of Modern Neurosurgery, 08(01), pp.109-118. 